\title{
THE DEVELOPMENT OF WOMEN'S LITERATURE IN CHINA IN THE FIRST HALF OF THE XX CENTURY
}

\author{
Shukriya Nazirova Miadovna \\ Senior Lecturer, Department of Chinese Philology, Faculty of Chinese Studies, Tashkent State \\ University of Oriental Studies
}

Article DOI: https://doi.org/10.36713/epra5305

\begin{abstract}
This research is about the development of an important part of Chinese literature -women's literature in $X X$ century. In the beginning of $X X$ century the number of women writers who wrote fiction works increased rapidly. The uneasy situations of the country such as revolutionary movements in the beginning of XX century, ChinaJapan war, monopole government of Mao Zedong, persecuting the democratic movements, deporting intelligent people to the "re-educating" camps and other conditions were not able to obstacle the women to enter the literature world. On the contrary, interfering of women in social-politic life of the country got stronger in the second part of the $X X$ century. The various movements of women, journals and newspapers and societies of women were organized. The role of women in social life became more noticeable and women literature developed more. Women writers such as Bin Sin, Lin Shukhua, Lu In, Din Lin, Syao Khun, Shi Pinmey, Dzao Min, Lyui Bichen, Chjan Aylin got an important place in social-politic and moral-cultural life of the country with their works. Many of these women participated actively in literary processes and public events. In this article some of the mentioned women writers' life and work will be discussed in detail. The women writers mentioned in this article are confessed not only in China, but also in the world's literature. The problems risen in women's works, the real events described by them play a significant role in gaining more knowledge about the history of China in the first half of $X X$ century and enriching our imaginations regarding to literature processes.

KEY WORDS: Literary ideology of Mao Zedong, women's literature, Bin Sin, children literature, Diaries "Letters for little pupils", Chzan Aylin.
\end{abstract}

\section{INTRODUCTION}

The purpose of the research is to study the development of women's literature in the first half of the twentieth century, its peculiarities, the work of the greatest representatives of Chinese literature, which is a unique literary phenomenon. Women's creativity is an integral part of the Chinese literary process. The emergence of women's literature in China dates back to very ancient times and covers a large period in terms of development. The state of China, the hearth of ancient civilization, has undergone many dangerous, conflicting political processes throughout its historical development. In particular, the twentieth century was a period of various revolutions and political upheavals. Women's literature also developed in tandem with the times.
Today, China has become a country with a female literary environment that is radically different from the ancient times when the names of women artists were used anonymously. "Women's Literature” 女性 文学 is officially used as a literary term in China. Women's creativity constitutes a huge literary heritage, and to this day its various aspects are being studied by world synologists. The work of such scientists as Yu.A. Kupriyanova, L.Li, Zhu Tszyn, Hong Jichen about the period in which we intend to think in the framework of this research makes our work a little easier. However, the monographic study of "women's literature" as a separate source of research in this period is extremely rare. 


\section{EPRA International Journal of Research and Development (IJRD)}

\section{Volume: 5 | Issue: 10 | October $2020 \quad$ - Peer Reviewed Journal}

\section{METHODS}

The works of writers whose names are scientifically recorded have been studied on the basis of sociological analysis and biographical analysis methods. The method of sociological analysis, which is one of the methods of contextual analysis, is useful in studying issues such as the relationship between the reality of the work of art and real reality, its level of historical authenticity, the relationship of artistic reality with the reality of life. It also reveals the nature of the issues raised by the writers, the close connection of the works of the writers of the period with the committed ideology of that period, the analysis of the ideological aspects of the works, the character traits of the protagonists, the nature of conflicts and the social roots of such artistic elements. The biographical method involves the study of a work of art in the context of the author's way of life.

\section{RESULTS AND DISCUSSION}

Scientists estimate that the 50 s and 70 s of the twentieth century marked the beginning of a new era in Chinese literature. There were several root reasons for this. To understand this correctly requires a little step back, a look at the history of the Chinese people in the early twentieth century. Two major socio-political events in the country's history in the early twentieth century: the Xinjiang Revolution (辛 亥革命) and the "May 4 Movement" (五四运动) intensified the influence of Western liberal views and philosophical thinking on Chinese public opinion. The main goal of the members of these movements was to create a New Culture by combining the traditional culture of China and the most positive advanced practices of Western science and culture. In the late 1920s, Mao Zedong's literary ideology became the leading ideology.

The development of "women's literature" as a separate phenomenon in modern Chinese literature dates back to this period and is directly related to the work of Bin Sin 冰心 and Din Lin 丁玲. The sociopolitical events that took place in the country in the early twentieth century led to an intensification of women's movements in the feminist spirit. As a result, many women turned to literature. Another important feature of this period is that if poetry had a high status in ancient Chinese literature, now by this time women were observed to begin to practice writing in prose.

The war that began with Japan in 1937 caused China to be divided territorially into several parts. As a result, different management systems had been formed in different regions, and writers living and working in these regions had different approaches to the same problems. War became the leading theme of the literature of this period.
In the 20 s and 30 s of the twentieth century, Bin Xin, Lin Shu Hua ${ }^{1}$, Lu Ying ${ }^{2}$, Ding Lin $^{3}$, Xiao Hong $^{4}$, Shi Pinmei ${ }^{5}$ entered the literary scene. Indeed, the work of each of these writers deserves to be studied as a separate object of study. The names of such writers can be cited many more. Their work has become the cornerstone of modern Chinese "women's literature." In this article, we will talk about some of them. If we look at their life and work, the influence of the social environment of that period on their way of life is clearly visible. All of them had higher education; most of them were children of educated and wealthy families, studied abroad and took an active part in the life of the country. But as victims of politics, they also served their sentences in "reeducation camps." In short, they experienced all the hardships of the period in their own destiny.

Bin Sin 冰心 (1900-1999) was a writer who left her mark on women's literature in the first half of the twentieth century. The author's real name was Se Vanin 谢婉莹 (her pseudonym was "Ice Heart"), who

\footnotetext{
${ }^{1}$ Lin Shu Hua (1900-1999) was a very famous master of prose, who at the same time taught Chinese language and literature at prestigious universities in China and London. (See: Хун Чзыцэн. Творчество писательниц/ в книге: История современной китайской литературы. - Пекин, 1999. - P.355-365)

${ }^{2}$ Lu Ying (1898-1934) - better known as Juan Ying and Juan Shui, is listed as one of the 18 most powerful female writers of modern Chinese literature due to her achievements in prose and journalism. (See: Хун Чзыцэн. Творчество писательниц/ в книге: История современной китайской литературы. - Пекин, 1999. P.355-365)

${ }^{3}$ Din Lin (1904-1986) - real name Jiang Bingji - author of the novels "Mother", "Sun on the Sangan River", a collection of about ten stories and short stories. (Сюй Хуабинь. Дин Лин Сяошо яньцзю. - Шанхай, 1990; Эйдлин Л.3. О китайской литературе наших дней. Москва, 1955; Насимова С. Психологозим личности героини произведения Дин Лин “Коровник"//”ХХитойшуносликнинг долзарб масалалари: филология, фалсафа, тарих, иқтисод ва сиёсат" XII Proceedings of the scientific-practical conference. - Тошкент, 2015 P.137-143; Насимова С. Проблематика и поэтика рассказа Дин Лин "Мэнкэ"/ "Шарқшуносликнинг долзарб масалалари илмий тўплами. -ТошДШИ, 2005.)

${ }^{4}$ Xiao Hong (1911-1942) is a great representative of the realist literature of the original name Zhang Nayinghita. She is the author of several books, including "Abandoned", "Life and Death Field". (See: Го Юйбин. Сяо Хун пинчуань (Сяо Хуннинг танқидий биографияси). Пекин, 2009; Лебедева Н.А. Сяо Хун. Жизнь. Творчество. Судьба. Дальнаука, 1998

${ }^{5}$ Shi Pinmey (1902-1928) is one of the four most talented women artists of the 20th century, despite her short life. (See:

https://www.abirus.ru/content/564/623/625/645/654/13222/ 13297.html)
} 


\title{
EPRA International Journal of Research and Development (IJRD)
}

\author{
Volume: 5 | Issue: 10 | October 2020
}

- Peer Reviewed Journal

has been engaged in art since the age of 7 . She studied at the American Christian Girls School in Beijing and later at Yangtze University. Due to the May 4 movement, she was forced to write under the pseudonym of Bin Sin. After graduating from university, she studied for a bachelor's degree in English literature in America. Bin Sin was not only a master of prose, but also translated works of world writers (such as R. Tagore, H. Jubron) into Chinese ${ }^{6}$. She also taught at various universities. Bin Sin began her career by writing short poems. Impressions of nature, life and death, happiness formed the thematic range of Bin Sin's poems, which later became the subject of her stories as well7. Bin Sin was also a major figure in Chinese children's literature. In her series of "Letters to Little Readers", she tells the story of a combination of the classic Chinese genre bitsi (short notes) and the traveler's diary style typical of European literature. The writer strives for an indepth and comprehensive analysis of children's inner world, their thoughts, their views of the reality around them, and the happiness of motherhood. These aspects of her work have also led to critical views. A number of Chinese critics, in particular Wang Zhefu, Xuan Ying, and Mao Dun, were critical of her work. In his book, "A New Style of Literary Movement in China", Wang Zhefu criticized Bin Xin's work, saying, "Her work is old-fashioned and outdated for a progressive society." The critic believed that the writer was entangled in the whirlpool of problems of family, domestic, school life, and considered the works to have no critical approach to social reality. Critic Xuan Ying, in his book "Modern Chinese Writers", he wrote: "she (Bin $\mathrm{Sin})$ is undoubtedly one of the typical representatives of the first famous writers and the new literary movement ... but what she understands are: a) motherly love; b) Ocean; c) only childhood memories"8. X. In also concluded that there was no in-depth analysis of social problems in the writer's work and criticized that the writer's style had traces of literature in the spirit of decadence left in the past ${ }^{9}$. Mao Dun noted on Bin Sin saying that "reality" was idealized and that a person with a "hungry stomach" could not find peace when reading her works. Mao Dun argued that there was no deep social context in the writer's work, and that the propensity for

\footnotetext{
6 Воробьева А. Творчество Бин Синь // Путь Востока. Общество. Политика. Религия. Материалы XI и XII молодежной научной конференции по проблемам философии, религии и культуры Востока - СПб: СанктПетербургское философское общество, 2009. - Р. 277 283.

Захарова Н. Бин Син и детская литература современного Китая.

${ }^{8}$ Ин Х. Сяньдай чжунго нюцзоцзя. - Шанхай, 1930 в

${ }^{9}$ Ин Х. Сяньдай чжунго нюцзоцзя. - Шанхай, 1930
}

mysticism was strong. She also believed that her protagonists were interpreted as weak, people who could not solve their own problems ${ }^{10}$. It is clear that all three critics had blamed the lack of social criticism in the writer's works as a shortcoming. Bin Sin remained true to her ideals and views for the rest of her life. The writer herself said: My heroes are little florists and I am an old florist. We cannot agree with the above critics. Bin Sin was a contemporary writer. In her 75-year career, she had always remained true to her views, she was not a fan of class interests. She was able to create realistic views about the lifestyles of ordinary people by raising topics such as little people (children), small problems in the family, the anxieties of mothers, school life.

World War II and the Civil War in China in the 1940 s led to a systemic change in the country. Naturally, the ideology of the ruling system has a profound effect on culture, art, and literature in the first place. Literature became a political weapon of the government. Various literary movements and trends developed. This, in turn, reflected the landscape of the literary environment of that period. Issues such as the tragedy of the people, the suffering of intellectuals during the war, the impact of the war on the fate of ordinary people, led to the creation of works of high artistic level. By the 1950s, Mao Zedong's literary ideology had become a decisive force throughout the country. At the heart of this ideology was the need to increase the socio-political effectiveness of literature. In a word, literature had to serve, subordinate, to serve class, political interests. This ideology forbade any creative freedom. As a result, many artists who opposed and did not support this policy went abroad. Most writers began to engage in translation. It was during these years that women's literature did not stop developing. On the contrary, many poets and writers entered the literary scene. Tsao Min ${ }^{11}$, Liu Bichen ${ }^{12}$, Zhang Aylin and dozens of other artists are among them. Zhang Aylin 张爱玲 (1920-1995) was one of the four most creative women (Liu Bichen, Shi Pinmei, Xiao Hong) recognized as the "most talented" in 20th century Chinese literature. Some aspects of Zhang Aylin's work have been studied by sinologists.

\footnotetext{
10 https://sanwen.ru/2012/05/10/bin-sin-zhizn-tvorchestvosudba/- (As of 29.09.2019)

${ }^{11}$ Tsao Min (1913) - her real name was Wu Xuanwen author of novels, essays and short stories such as "Dangerous Place", "Moving Force", "Locomotive", "Against the Wind and Waves" (See: Литературный энциклопедический словарь./https://literary_encyclopedia.academic.ru/5333/Ц $\mathrm{AO} \mathrm{MИH}$

${ }^{12}$ Liu Bichen (1883-1943) was the first female editor in Chinese history, a public figure who fought for women's rights in China, and a poet.
} 


\section{EPRA International Journal of Research and Development (IJRD)}

Including Leo $\mathrm{Li}^{13}$, Li Oufan ${ }^{14}$, Nicole Juan ${ }^{15}$, Van Ani $^{16}$, Yu.A. Kupriyanova ${ }^{17}$ 's works were some of them.

Although Zhang Aylin began her career at the age of 11 , the writer's true popularity came from the work she did during her time in Shanghai. Due to the political situation, the writer's life was spent in Hong Kong and Shanghai. Her novels "Love in an Abandoned City" 傾城之戀, "Golden Chains" 金锁 记, "Love on a Burnt Land", 赤地之戀, "Gossip" 流 言 brought her unprecedented popularity. In 1955, Aylin was forced to leave the country for the United States. During her time in exile, Aylin translated famous examples of Chinese literature into English. She is known not only as a writer, educator, translator, but also as a film director. Films based on her works have also been made.

All the above-mentioned writers made an invaluable contribution to the formation of modern Chinese literature in the first half of the twentieth century. The study of the significant literary heritage created by them is one of the important tasks facing Uzbek sinologists.

\section{CONCLUSION}

In the first half of the twentieth century, various socio-political changes took place in China, and literature became an important front that reflected these changes.

Two different directions had emerged in the approach to literature. While one group of writers turned literature into a weapon of ideology based on class interests, the second group of writers demonstrated the function of literature as a mirror of the period, a powerful force that could realistically reflect reality. But an important aspect of the writers of both groups was that they adhered to the criteria of fiction as much as possible, adhering to the principles of not over-documenting the literature.

The role and importance of women artists in the literary environment of this period was incomparable. Writers who kept pace with the times

\footnotetext{
${ }^{13}$ Huang N. Introduction//Chang E. Written on water. New York, 2004. P.IX-XXVII

${ }^{14} \mathrm{Li}$ Oufan. Shanghai modeng - yi zhonvg dushi wenhua zai shanghai 1930-1945. - Beijing, 2001

15 Lee L. Shanghai modern: The Flowering of a New Urban Culture in China 1930-1945. - Cambridge MA, 1999

16 Ван Аньи. Такая обычная и земная Чжан Айлин.// Китайские метамарфозы:современная китайская художественная пароза и эссеистика/ Составитель и ответственный редактор Д.Н Воскресенского. Москва, 2007.

17 Куприянова Ю.А. Образ новой женщины Китая в середины XX века в творчестве Чжан Айлин/Вестник СпбГУ. Сер. 13. 2014. Выпуск 4.- с.100-107
}

were not indifferent to the most important events in social life, on the contrary, all the hardships had a serious impact on their lives as well.

Representatives of "Women's Literature" created works on various topics, in different genres, reflecting the current issues of the time, especially in the field of storytelling and novels. Translation literature evolved.

In most of the works created during this period, the writers wrote about their own experiences, which they witnessed firsthand. The feminist spirit was strongly manifested not only in socio-political life but also in literature. WOMAN became the main protagonist of the works of art. The image of problems such as her destiny, her thoughts, her place in the family, her rights and position came to the fore.

The style of the writers combined the traditions of traditional literature and the experience of Western writers who came in thanks to translations from world literature which led the way in a realistic depiction of reality.

The literature of the first half of the twentieth century laid an important foundation and ground for the literature of the period after it.

\section{BIBLIOGRAPHY}

1. Harrison J.P. The Long March to Power. A History of the Chinese Communist Party / J.P. Harisson. - New York - Washington : International Thomson Publishing, 1972

2. Асланов Р.М. Три модели и перспективы сочиализма в КНР//Восток-Россия-Запад: Ист. и культурол.исслед: К 70-летию акад. В.С.Мясникова. - М., 2001

3. Бергстен Ф., Гилл Б., Ларди Н., Митчелл Д. Китай. Что следует знать о новой сверхдержаве. - М.: Институт комплексных стратегических исследований, 2007

4. Бондарева В.В. Культура и «культурная революичи» в КНP (1966-1976 г2.): соотношение понятий/ В.В.Бондарева// Гарни 2004: материаль Научной сессии ФИСМО (факультет истории, сочиологии и международных отношений). - Краснодар: Кубанский государственный университет, 2004

5. Демидо Н.Ю. Чжан Цзе/Духовная культура Китая: энииклопедия: в 5 m. Москва, Восточная литература, 2006. -T.3

6. Кореч Г.Б. //Духовная культура Китая: энциклопедия: в $5 \mathrm{~m}$. Москва, Восточная литература, 2006. - T.3

7. Львов Д.В. Жизнь и творчество современной китайской писательницы Ван Аньи. - Санкт Петербург, 2007. (автореф. дисс. на соис. кан.филол.н.)

8. Никитина А.А. Эволючия персоносферы китайской прозы второй половины ХХ ВЕКА.- 


Санкт Петербург, 2017 (дисс.на

соис.кан.филол.н.)

9. Усов В.Н. "Культурная револючия" в Китае //В книге: История в лицах и событиях. Москва, Политиздат, 1991

10. http://russian.cri.cn/1070/2009/06/02/1s293519. $\underline{\text { htm }}$ 